\title{
Upaya Meningkatkan Prestasi Belajar Matematika Tentang Pengurangan dengan Model Pembelajaran Kontekstual Siswa Kelas 1 Semester II Sekolah Dasar
}

\author{
Sunarsih* \\ SD Negeri 2 Gatak Klaten \\ *sunarsih@gmail.com
}

\begin{abstract}
This classroom action research is motivated by the low mathematics learning outcomes, especially in the reduction material. This study aims to improve student learning outcomes on Mathematics about the reduction by using contextual learning models are expected to improve student learning outcomes. The contextual learning method is a learning concept that helps teachers associate the material they teach with real-world student situations and encourage students to make connections between the knowledge he has and its application in their daily lives. The method used in this study is Classroom Action Research (PTK) with the object of research in class I SD Negeri 2 Gatak. The focus of the research on the reduction of contextual learning is an effort to improve the learning outcomes of Mathematics. Data collection is done by direct observation of the learning process. The results showed that there was a significant increase of student learning outcomes in pre-cycle learning activities, cycle I and cycle II. The increase can be seen from the average value of students and the percentage of completeness of learning outcomes from KKM which is determined at 65 . Based on the results of these observations it can be concluded that the application of Mathematics subject matter reduction learning contextual learning models can improve student learning outcomes in class I SD Negeri 2 Gatak. Furthermore, the results of this study can be used to improve learning with similar cases.
\end{abstract}

\begin{abstract}
Abstrak: Penelitian tindakan kelas ini dilatar belakangi oleh rendahnya hasil belajar Matematika khususnya pada materi pengurangan. Penelitian ini bertujuan untuk meningkatkan hasil belajar siswa pada mata pelajaran Matematika tentang pengurangan dengan menggunakan model pembelajaran kontekstual diharapkan dapat meningkatkan hasil belajar siswa.Metode pembelajaran kontekstual adalah konsep belajar yang membantu guru mengaitkan antara materi yang diajarkannya dengan situasi dunia nyata siswa dan mendorong siswa membuat hubungan antara pengetahuan yang dimilikinya dengan penerapannya dalam kehidupan mereka sehari-hari. Metode yang digunakan dalam penelitian ini adalah Penelitian Tindakan Kelas (PTK) dengan obyek penelitian siswa kelas I SD Negeri 2 Gatak. Fokus penelitian pada pengurangan dengan pembelajaran kontekstual sebagai upaya meningkatkan hasil belajar Matematika. Pengumpulan data dilakukan dengan pengamatan langsung terhadap proses pembelajaran. Hasil penelitian menunjukkan bahwa terdapat peningkatan yang signifikan dari hasil belajar siswa pada kegiatan pembelajaran pra siklus, siklus I dan siklus II. Peningkatan tersebut dapat dilihat dari besarnya nilai rata-rata siswa dan prosentase ketuntasan hasil belajar dari KKM yang ditentukan sebesar 65. Berdasarkan dari hasil observasi tersebut dapat disimpulkan bahwa penerapan model pembelajaran kontekstual mata pelajaran Matematika materi pengurangan dapat meningkatkan hasil belajar siswa kelas I SD Negeri 2 Gatak. Selanjutnya hasil penelitian ini dapat dijadikan untuk perbaikan pembelajaran dengan kasus serupa.
\end{abstract}

Kata Kunci: Model Pembelajaran Kontekstual, Pengurangan, Meningkatkan Hasil Belajar Siswa. 


\section{Pendahuluan}

Undang-Undang nomor 20 tahun 2003 tentang Sistem Pendidikan Nasional dalam penjelasan menegaskan bahwa manusia membutuhkan pendidikan dalam kehidupannya. Mengingat peranan pendidikan yang sangat kompleks, maka penyelenggaraan pendidikan pada setiap jenjangnya harus berpedoman pada seperangkat aturan dan rencana tentang pendidikan yang dikemas dalam bentuk kurikulum dimana matematika menjadi salah satu mata pelajaran yang diajarkan.Mata pelajaran matematika merupakan mata pelajaran yang sangat diperlukan untuk memecahkan suatu permasalahan yang ada dalam kehidupan sehari-hari. Oleh karena itu, matematika diajarkan sejak dini di Sekolah Dasar.

Matematika merupakan ilmu yang memegang peranan penting, baik dalam kehidupan seharihari maupun dalam perkembangan ilmu dan teknologi. Matematika timbul karena pikiran-pikiran manusia yang berhubungan dengan ide, proses, dan penalaran. Matematika merupakan nilai praktis, nilai disiplin, dan nilai budaya [1][2]. Sedangkan menurut Kamus Besar Bahasa Indonesia Matematika adalah ilmu tentang bilangan-bilangan, hubungan antar bilangan, dan prosedur operasional yang digunakan dalam penyelesaian penyelesaian mengenai bilangan.

Pengurangan adalah proses, cara perbuatan mengurangi atau mengurangkan. (Anton M. Moeliono, 1993: 616). Operasi pengurangan menurut Van De Walle (2006:155), jika salah satu bagiannya dan totalnya sudah diketahui maka pengurangan akan menghasilkan bagian yang satunya. Hasil belajar adalah kemampuan-kemampuan yang dimiliki siswa setelah ia menerima pengalaman belajarnya [1][3]. Berdasarkan pengamatan di lapangan dalam pembelajaran matematika guru cenderung menyampaikan dengan metode ceramah yang verbalistik sehingga siswa tidak aktif, kurang memahami konsep dan tidak menemukan sendiri pengetahuan dan keterampilannya sehingga hasil belajarnya pun di bawah standar. Hal ini ditunjukan dengan perolehan hasil belajar siswa yang rendah dari 18 siswa hanya 6 siswa mendapat nilai diatas 65 , dan 12 siswa mendapat nilai dibawah 65 atau baru mencapai tingkat penguasaan materi di bawah $65 \%$.

Pembelajaran kontekstual (Contextual Teaching and learning) adalah konsep belajar yang membantu guru mengaitkan antara materi yang diajarkannya dengan situasi dunia nyata siswa dan mendorong siswa membuat hubungan antara pengetahuan yang dimilikinya dengan penerapannya dalam kehidupan mereka sehari-hari, dengan melibatkan tujuh komponen utama pembelajaran efektif, yakni: konstruktivisme (Constructivism), bertanya (Questioning), menemukan ( Inquiri), masyarakat belajar (Learning Community), pemodelan (Modeling), dan penilaian sebenarnya (Authentic Assessment)[4][5]. Pembelajaran Kontekstual dapat diterapkan dalam kurikulum apa saja, bidang studi apa saja, dan kelas yang bagaimanapun keadaannya.

Perbedaan Pendekatan Kontekstual dengan Pendekatan Tradisional

Kontekstual

1. Menyandarkan pada pemahaman makna.

2. Pemilihan informasi berdasarkan kebutuhan siswa.

3. Siswa terlibat secara aktif dalam proses pembelajaran.

Tradisional

1. Menyandarkan pada hapalan

2. Pemilihan informasi lebih banyak ditentukan oleh guru.

3. Siswa secara pasif menerima informasi, khususnya dari guru.

Tujuh komponen pembelajaran kontekstual: (1) Konstruktivisme, (2)Inquiry, (3) Questioning (Bertanya), (4) Learning Community (Masyarakat Belajar), (5) Modeling (Pemodelan), (6) Reflection ( Refleksi), (7) Authentic Assessment (Penilaian Yang Sebenarnya). Karakteristik pembelajaran kontekstual: Kerjasama; Saling menunjang; Menyenangkan, tidak membosankan; Belajar dengan bergairah; Pembelajaran terintegrasi; Menggunakan berbagai sumber; Siswa aktif; Sharing dengan teman; Siswa kritis guru kreatif.

Berdasarkan latar belakang yang telah disampaikan di atas, rumusan masalah dalam penelitian ini adalah apakah penerapan model pembelajaran Kontekstual dapat meningkatkan Hasil Belajar matematika tentang pengurangan pada siswa kelas I SD Negeri 2 Gatak Klaten Tahun Pelajaran $2016 / 2017 ?$ 
Berdasarkan rumusan tersebut maka tujuan dari penelitian ini adalah mendiskripsikan hasil belajar matematika tentang materi pengurangan dengan menggunakan model pembelajaran kontekstual pada siswa kelas I SD Negeri 2 Gatak Klaten Tahun Pelajaran 2016/ 2017.

\section{Metode Penelitian}

Subjek penelitian ini merupakan responden yang akan dijadikan sasaran penelitian dan dijadikan sebagai bahan pengambilan data informasi sesuai dengan kebutuhan penelitian. Adapun subjek penelitian ini adalah siswa kelas I SD Negeri 2 Gatak berjumlah 18 siswa yang terdiri dari 8 laki-laki, dan 10 perempuan.Mata pelajaran yang dilakukan penelitian adalah pelajaran Matematika dengan materi pengurangan. Dalam penelitian dilaksanakan di SD Negeri 2 Gatak,Kecamatan Delanggu,Kabupaten Klaten Semester II Tahun Pelajaran 2016/ 2017.

\section{Hasil dan Pembahasan}

\section{a. Hasil Penelitian}

1) Pra Siklus

Data hasil belajar siswa kelas I tentang pengurangan sebagai berikut:

Tabel 1. Daftar Nilai Hasil Ulangan Pra Siklus Kelas 1 Mata Pelajaran Matematika

\begin{tabular}{|c|c|c|c|c|}
\hline No & No. Induk & Nama & $\mathbf{L} / \mathbf{P}$ & Nilai \\
\hline 1 & 3260 & Amelda Diva Velisya & $\mathrm{P}$ & 50 \\
\hline 2 & 3261 & Andhika Aswangga A. & $\mathrm{L}$ & 60 \\
\hline 3 & 3262 & Ayudia Putri Veronica & $\mathrm{P}$ & 70 \\
\hline 4 & 3263 & Bellya Surya Fadila & $\mathrm{P}$ & 70 \\
\hline 5 & 3264 & Dellya Surya Fadila & $\mathrm{P}$ & 70 \\
\hline 6 & 3265 & Eno Deeya Ramadhani & $\mathrm{P}$ & 60 \\
\hline 7 & 3266 & Faiz Zumalon & $\mathrm{L}$ & 70 \\
\hline 8 & 3267 & Fitrah Lanang R. & $\mathrm{L}$ & 50 \\
\hline 9 & 3268 & Galang Setya Purnama & $\mathrm{L}$ & 70 \\
\hline 10 & 3269 & Gendhis Sekar Arum & $\mathrm{P}$ & 60 \\
\hline 11 & 3270 & Imelda Ardinata & $\mathrm{P}$ & 40 \\
\hline 12 & 3271 & Lutfi Ikhsanudin S. & $\mathrm{L}$ & 40 \\
\hline 13 & 3272 & Muh. Nur Arifin & $\mathrm{L}$ & 50 \\
\hline 14 & 3273 & Naia Widia Alifia & $\mathrm{P}$ & 70 \\
\hline 15 & 3274 & Nasya Nudya A. & $\mathrm{P}$ & 60 \\
\hline 16 & 3275 & Novandra Agung P. & $\mathrm{L}$ & 50 \\
\hline 17 & 3276 & Raka Arta Alfiano & $\mathrm{L}$ & 50 \\
\hline 18 & 3277 & Salma Tri Rachmawati & $\mathrm{P}$ & 60 \\
\hline \multicolumn{4}{|c|}{ Jumlah } & 1054 \\
\hline \multicolumn{4}{|c|}{ Nilai tertinggi } & 70 \\
\hline \multicolumn{4}{|c|}{ Nilai terendah } & 40 \\
\hline \multicolumn{4}{|c|}{ Rata-rata } & $\mathbf{5 8 , 5 7}$ \\
\hline
\end{tabular}


Berdasarkan nilai siswa di atasdalam Mata Pelajaran Matematika materi pengurangan Kelas I semester II nilai rata-rata kelas 58,57. Prosentase nilai kurang dari KKM (nilai 65) adalah 66,67\% yaitu sekitar 12 anak dari jumlah keseluruhan 18 anak.

2) Siklus I

Perbaikan pembelajaran siklus I dilaksanakan pada hari Selasa, 19 April 2017. Secara lengkap hasil perbaikan pembelajaran siklus I dapat dilihat pada tabel terlampir.

Tabel 2 Daftar Nilai Hasil Perbaikan Pembelajaran Siklus I

Kelas 1 Mata Pelajaran Matematika

\begin{tabular}{cclcc}
\hline No & No. Induk & \multicolumn{1}{c}{ Nama } & L/ P & Nilai \\
\hline \hline 1 & 3260 & Amelda Diva Velisya & $\mathrm{P}$ & 70 \\
2 & 3261 & Andhika Aswangga A. & $\mathrm{L}$ & 80 \\
3 & 3262 & Ayudia Putri Veronica & $\mathrm{P}$ & 70 \\
4 & 3263 & Bellya Surya Fadila & $\mathrm{P}$ & 70 \\
5 & 3264 & Dellya Surya Fadila & $\mathrm{P}$ & 80 \\
6 & 3265 & Eno Deeya Ramadhani & $\mathrm{P}$ & 70 \\
7 & 3266 & Faiz Zumalon & $\mathrm{L}$ & 60 \\
8 & 3267 & Fitrah Lanang R. & $\mathrm{L}$ & 70 \\
9 & 3268 & Galang Setya Purnama & $\mathrm{L}$ & 70 \\
10 & 3269 & Gendhis Sekar Arum & $\mathrm{P}$ & 50 \\
11 & 3270 & Imelda Ardinata & $\mathrm{P}$ & 60 \\
12 & 3271 & Lutfi Ikhsanudin S. & $\mathrm{L}$ & 70 \\
13 & 3272 & Muh. Nur Arifin & $\mathrm{L}$ & 60 \\
14 & 3273 & Naia Widia Alifia & $\mathrm{P}$ & 80 \\
15 & 3274 & Nasya Nudya Amburika & $\mathrm{P}$ & 70 \\
16 & 3275 & Novandra Agung P. & $\mathrm{L}$ & 80 \\
17 & 3276 & Raka Arta Alfiano & $\mathrm{L}$ & 60 \\
18 & 3277 & Salma Tri Rachmawati & $\mathrm{P}$ & 70 \\
\hline \multicolumn{7}{c}{ Jumlah } & & $\mathbf{1 2 4 0}$ \\
\hline \multicolumn{7}{c}{ Nilai tertinggi } & & $\mathbf{8 0}$ \\
\hline \hline
\end{tabular}

Hasil evaluasi siklus I menunjukkan peningkatan dibandingkan dengan pra siklus, siswa yang memperoleh nilai $\geq$ KKM sebelumnya hanya berjumlah 6 siswa atau 33,33\% naik menjadi 12 atau 66,66 \% dari keseluruhan siswa kelas I. Data nilai evaluasi yang menunjukkan adanya peningkatan dapat dilihat setelah diadakan perbaikan pembelajaran pada siklus pertama disajikan dalam bentuk tabel, perbandingan pra siklus dan siklus I sebagai berikut: 
Tabel 3 Perbandingan Hasil Evaluasi Pra Siklus dan Siklus I

\begin{tabular}{cccc}
\hline \hline \multirow{2}{*}{$N o$} & Nilai & \multicolumn{2}{c}{ Jumlah Siswa } \\
\cline { 2 - 4 } & & Pra Siklus & Siklus I \\
\hline 1 & 100 & - & - \\
2 & 90 & - & - \\
3 & 80 & - & 4 \\
4 & 70 & 6 & 8 \\
5 & 60 & 5 & 5 \\
6 & 50 & 5 & 1 \\
7 & 40 & 2 & - \\
8 & 30 & - & - \\
\hline & Jumlah & $\mathbf{1 8}$ & $\mathbf{1 8}$ \\
\hline \multicolumn{2}{r}{ Siswa yang tuntas belajar } & $\mathbf{5 8 , 5 7}$ & $\mathbf{6 8 , 5 7}$ \\
\hline Siswa yang tidak tuntas belajar & $\mathbf{6}$ & $\mathbf{1 2}$ \\
\hline
\end{tabular}

Pada tabel perbandingan hasil nilai pra siklus dan siklus I diperoleh perbandingan siswa yang belum tuntas belajar sebelumnya 12 orang berkurang menjadi 6 orang. Rata-rata nilai yang sebelumnya hanya 58,57 meningkat menjadi 68,57.

\section{Hasil Refleksi}

Berdasarkan hasil belajar pada siklus I menghasilkan data dan informasi sebagai berikut.

1) Jumlah peserta ulangan harian 18 siswa

2) Jumlah siswa yang memperoleh nilai $\geq 65$ sebanyak 12 siswa

3) Jumlah siswa yang memperoleh nilai $<65$ sebanyak 6 siswa

4) Nilai rata - rata kelas 68,57

5) Ketuntasan klasikal 66,66\%

3) Siklus II

Perbaikan pembelajaran siklus II dilaksanakan pada hari Selasa, tanggal 26 April 2017 dengan objek adalah siswa Kelas ISD Negeri 2 Gatak. Data hasil belajar siswa kelas I tentang pengurangan sebagai berikut:

Tabel 4 Daftar Nilai Hasil Perbaikan Pembelajaran Siklus II

Kelas 1 Mata Pelajaran Matematika

\begin{tabular}{clcc}
\hline No & \multicolumn{1}{c}{ Nama } & L/ P & Nilai \\
\hline 1 & Amelda Diva Velisya & $\mathrm{P}$ & 80 \\
2 & Andhika Aswangga A. & $\mathrm{L}$ & 90 \\
3 & Ayudia Putri Veronica & $\mathrm{P}$ & 70 \\
4 & Bellya Surya Fadila & $\mathrm{P}$ & 70 \\
5 & Dellya Surya Fadila & $\mathrm{P}$ & 90 \\
6 & Eno Deeya Ramadhani & $\mathrm{P}$ & 70
\end{tabular}




\begin{tabular}{clcc}
7 & Faiz Zumalon & $\mathrm{L}$ & 70 \\
8 & Fitrah Lanang R. & $\mathrm{L}$ & 80 \\
9 & Galang Setya Purnama & $\mathrm{L}$ & 80 \\
10 & Gendhis Sekar Arum & $\mathrm{P}$ & 80 \\
11 & Imelda Ardinata & $\mathrm{P}$ & 80 \\
12 & Lutfi Ikhsanudin S. & $\mathrm{L}$ & 70 \\
13 & Muh. Nur Arifin & $\mathrm{L}$ & 60 \\
14 & Naia Widia Alifia & $\mathrm{P}$ & 80 \\
15 & Nasya Nudya Amburika & $\mathrm{P}$ & 70 \\
16 & Novandra Agung P. & $\mathrm{L}$ & 70 \\
17 & Raka Arta Alfiano & $\mathrm{L}$ & 70 \\
18 & Salma Tri Rachmawati & $\mathrm{P}$ & 70 \\
\hline & Jumlah & & $\mathbf{1 5 6 0}$ \\
\hline \hline & Nilai tertinggi & & $\mathbf{9 0}$ \\
\hline \hline & Nilai terendah & & $\mathbf{7 5 , 0 0}$ \\
\hline \hline
\end{tabular}

Berdasarkan analisis hasil tes siklus II dan gambar diagram di atas dalam nilai ratarata kelas 75,00 . Siswa yang tuntas 17 siswa dengan prosentase ketuntasan belajar kurang lebih 95,23 \%. Hal ini menunjukkan bahwa yang dilakukan oleh guru sudah berhasil meningkatkan prestasi siswa sesuai dengan hasil yang diharapkan dalam menguasai materi Mata Pelajaran Matematika materi pengurangan. Setelah kedua siklus perbaikan pembelajaran dilaksanakan terdapat kemajuan yang semakin meningkat, tingkat kemajuan tersebut dapat dilihat pada tabel berikut ini.

Tabel 5. Peningkatan Ketuntasan Hasil Belajar dan Nilai Rata-rata

\begin{tabular}{cccccccc}
\hline \multirow{2}{*}{ NO } & \multirow{2}{*}{ Kriteria } & \multicolumn{2}{c}{ Pra Siklus } & \multicolumn{2}{c}{ Siklus I } & \multicolumn{2}{c}{ Siklus II } \\
\cline { 3 - 8 } & & Jumlah & $\mathbf{\%}$ & Jumlah & $\mathbf{\%}$ & Jumlah & $\%$ \\
\hline 1. & Tuntas & 6 & $33,33 \%$ & 12 & $66,66 \%$ & 17 & $95,23 \%$ \\
2. & Belum & 12 & $66,66 \%$ & 6 & $33,33 \%$ & 1 & $4,76 \%$ \\
& Tuntas & & & & & & 75,00 \\
3. & Nilai & \multicolumn{2}{c}{58,57} & & 68,57 & & 75 \\
\hline
\end{tabular}

\section{Hasil Refleksi}

Peningkatan hasil perbaikan pembelajaran dari pembelajaran sebelum perbaikan sampai dengan perbaikan pembelajaran siklus II dapat dilaporkan sebagai berikut :

1) Hasil evaluasi sebelum perbaikan
a) Rata-rata nilai
: 58,57
b) Jumlah siswa yang tuntas
: 6 

c) Jumlah siswa yang belum tuntas
: 12
d) Prosentase ketuntasan belajar
: $33,33 \%$

2) Hasil evaluasi siklus I
a) Rata-rata nilai
: 68,57
b) Jumlah siswa yang tuntas
12
c) Jumlah siswa yang belum tuntas
: 6
d) Prosentase ketuntasan belajar
: $66,66 \%$

3) Hasil evaluasi siklus II
a) Rata-rata nilai
: 75,00
b) Jumlah siswa yang tuntas
: 17
c) Jumlah siswa yang belum tuntas
: 1
d) Prosentase ketuntasan belajar
: $95,23 \%$

b. Pembahasan

1) Siklus I

Pada perbaikan pembelajaran siklus I keaktifan siswa kurang optimal, hal ini terjadi karena siswa belum terbiasa melakukan kegiatan pembelajaran dengan model kontekstual. Kerja sama antar anggota kelompok belum tampak. Kegiatan siswa dalam kelompok masih didominasi oleh siswa tertentu yang biasa mendapatkan nilai tinggi di kelasnya. Dalam kegiatan diskusi kebanyakan siswa masih belum percaya diri untuk mengemukakan pendapat. Masih belum optimalnya keterlibatan siswa dalam pembelajaran pada siklus I yang berakibat pada rendahnya tingkat pemahaman siswa terhadap materi pembelajaran yang disajikan oleh guru. Pada perbaikan siklus I tingkat ketuntasan klasikal walaupun meningkat, tetapi masih sangat rendah, yaitu 33,33\% dengan nilai rata-rata 58,57. Siswa yang turut aktif dalam kegiatan pembelajaran, turut menemukan konsep akan lebih mudah memahami dan mengerti tentang materi pembelajaran dibandingkan siswa yang pasif, hanya sekedar melihat dan mengamati [6][7].

2) Siklus II

Hasil dari siklus II dapat dijelaskan sebagai berikut; tingkat ketuntasan mencapai 95,23\%, meskipun belum mencapai 100\% namun dapat dikatakan telah memenuhi kriteria dalam mencapai ketuntasan. Kriteria yang memenuhi standar ketuntasan belajar adalah $85 \%$. Dengan hasil siklus II tersebut, walaupun secara klasikal dapat dikatakan tuntas, akan tetapi masih terdapat beberapa anak yang belum berhasil mencapai hasil tuntas karena berbagai faktor kendala masih dialami oleh siswa tertentu. Batas nilai tuntas telah ditetapkan bersama saat penyusunan Kurikulum Tingkan Satuan Pendidikan, yaitu KurikulumSD Negeri 2 Gatak, yang menetapkan kriteria ketuntasan minimal untuk mata pelajaran matematika kelas I adalah 65, dengan demikian masih terdapat 1 siswa yang belum mencapai ketuntasan dengan prosentase yang belum tuntas $4,76 \%$ [8].

\section{Kesimpulan}

Setelah melaksanakan perbaikan pembelajaran dan berdasarkan hasil pengolahan data dapat ditarik kesimpulan sebagai berikut : Bahwa dengan model Metode Kontekstual dapat meningkatkan hasil belajar Matematika materi pengurangan pada siswa kelas I SD Negeri 2 Gatak Kecamatan Delanggu Kabupaten Klaten Tahun Pelajaran 2016/ 2017.

Berdasarkan hasil evaluasi pra siklus jumlah siswa yang belum mencapai ketuntasan 12 siswa dengan prosentase $66,66 \%$ dan yang sudah mencapai ketuntasan 6 siswa dengan prosentase $33,33 \%$ dengan rata-rata 58,57. Siklus I jumlah siswa yang belum mencapai ketuntasan 6 siswa dengan prosentase $33,33 \%$ dan siswa yang mencapai ketuntasan 12 siswa dengan prosentase $66,66 \%$ dengan rata-rata 68,57 . Siklus II jumlah siswa yang belum mencapai ketuntasan 1 siswa 
dengan prosentase $4,76 \%$ dan siswa yang mencapai ketuntasan 17 siswa dengan prosentase $95,23 \%$ dengan rata-rata 75,00 .

\section{Referensi}

[1] Sudjana, Nana. (1990). Penelitian Hasil Proses Belajar Mengajar. Bandung: Remaja Rosda Karya.

[2] Mufti, Ali. 1989. Penelitian Hasil Belajar. Surabaya: Usaha nasional.

[3] Djamarah, Syaiful Bahri. 1994. Prestasi Belajar dan Kompentensi Guru. Surabaya: Usaha Nasional.

[4] Harahap, Nasrun. 1994. Penelitian Hasil Belajar. Surabaya : Usaha Nasional

[5] Kunandar. 2007. Guru Profesional. Jakarta: PT Raja Grafindo Persada

[6] Slavin, Robert E. 2008. Cooperatif Learning. Bandung: Penerbit Nusa Media..

[7] Isjoni. 2007. Cooperative Learning. Bandung: Alfa Beta

[8] Wena, Made. 2009. Strategi Pembelajaran Inovatif Kontemporer Suatu Tinjauan Operasional. Jakarta: Bumi Aksara. 